\title{
ANNUAL SALT AND ENERGY BUDGET BENEATH AN ANTARCTIC FAST ICE COVER
}

\author{
by
}

\author{
ian Aluison, C. M. Tivendale and G. R Copson
}

Antarctic Division, Kingston, Tasmania 7150, Australia

\section{ABSTRACT}

Water temperature and salinity profiles were measured to a depth of $300 \mathrm{~m}$ below a fast ice cover near Mawson, Antarctica over a full annual cycle. Together with measurements of ice thickness and salinity, they are used to determine the heat and salt balance of the ice/ocean system at this site. The energy balance of the ocean is related to measured energy fluxes at the surface.

Throughout the winter there is a net advection of salty water to the site which enhances the salinity increase in the water due to brine ejected from ice. After the ice reaches its maximum thickness there is considerable advection of warmer water which both raises the water temperature at the site and provides heat for the large oceanic heat flux previously reported for Mawson. The rate of this heat advection increases as the ice extent around Antarctica decreases. The ice partially melts in situ and breaks out in mid January. This effective removal of fresh water is balanced by a large influx of melt water from the continental ice sheet. The fresh water, initially near the surface, becomes well mixed to depths of greater than $200 \mathrm{~m}$ by strong storms in the ice free period from mid January to early April.

\section{INTRODUCTION}

Rejection of brine by a growing sea ice cover gives rise to density instabilities and hence vertical convection in the upper layers of the ocean. In the Antarctic, where the degree of salt stratification of the surface water is much less than in the Arctic, this winter haline convection can reach depths of hundreds of metres. It results in the formation of the typical cold, isothermal Antarctic Winter Water from the stratified warmer and fresher Summer Surface Water. The convection can lead to salinity increase in the entire continental shelf water column and may play a role in the formation of Antarctic Bottom Water (Foster and Carmack 1976).

Several studies in the Arctic have looked at the full seasonal development of the ocean mixed layer structure beneath, for example, drifting sea ice in the Beaufort Sea (AIDJEX) or beneath an annual ice cover in a shallow bay (Lewis and Walker 1970). Similar studies for the Antarctic have usually been confined to the period of winter ice growth (eg Brennecke 1921, Neal and others 1976, Wakatsuchi 1982) and it is believed that the data presented in this paper represents one of the first hydrographic studies for the Antarctic covering a full season of ice growth, ice decay, and the open water summer period. These data are available for an area where surface energy balance measurements were also made.

\section{OBSERVATIONAL METHODS}

The hydrographic data presented are for a site in Kista Strait $\left(67^{\circ} 36^{\prime} \mathrm{S}, 63^{\circ} 51\right.$ 'E) about $1.5 \mathrm{~km}$ north west of Mawson Station. Kista Strait is about $1 \mathrm{~km}$ wide, bounded by groups of low islands, and has a depth generally in excess of $350 \mathrm{~m}$. The strait is open to the north east and the Antarctic ice sheet terminates at ice cliffs $30 \mathrm{~m}$ above sea level, $1.5 \mathrm{~km}$ south of the hydrographic site.

Salinity and temperature data for the site were measured with a Seabird SBE-3 thermistor and a SBE-4 conductivity probe. In winter the instruments were lowered through a hole in the ice using a battery powered portable winch and during the ice free period the same system was operated from an amphibian craft. Depth was recorded from marks on the hydrographic cable. The salinity measurements were calibrated against regular bottle samples measured with a laboratory salinometer, and during February 1981 the data from the Seabird CT system was checked agaist a number of casts in Kista Strait made with a Neil Brown Mark III CTD system on board the resupply vessel Nella Dan.

Although the data cover a full annual cycle, they were not all collected in one year. Data from October to February were collected during $1980 / 81$ with one or more casts weekly being made between October and mid January and one cast every two weeks from mid January until the end of February. Data from April to October were collected during 1982 at the rate of about one cast per month. The salinity and temperature profiles measured in October 1980 and October 1982 were identical to within better than $0.02 \%$ and $0.01{ }^{\circ} \mathrm{C}$ and the two data sets have been combined to give one set covering a full season.

The conductivity-temperature system used was not capable of measuring continuous profiles and therefore only discrete measurements were made. During 1980/81 readings were made at every $5 \mathrm{~m}$ or more frequently to a depth of $50 \mathrm{~m}$ and from there at least at $10 \mathrm{~m}$ intervals to the bottom. In 1982 the readings were taken every $10 \mathrm{~m}$ to a depth of $50 \mathrm{~m}$ depth and thence at every $20 \mathrm{~m}$ to the bottom.

Sea ice salinities were measured with a laboratory salinometer on $0.2 \mathrm{~m}$ sections of ice cores. The ice cores were sampled immediately after collection.

\section{SEASONAL VARIATIONS IN TEMPERATURE AND SALINITY}

Typical measured profiles of salinity and temperature throughout the year are shown in Figure 1. For convenience these have been split into two periods; firstly a period of ice growth fom mid February until October, when the cooling of the open water prior to freeze-up occurs, followed by ice formation, and ice growth, and secondly a period of ice decay from October until mid February, when thinning of the ice cover by bottom ablation, breakout, and warming of the open water occur.

In mid February the surface water is at its warmest with a strong pycnocline at about $200 \mathrm{~m}$ separating the warm relatively fresh Antarctic Summer Surface Water from underlying remnants of last season's Winter Water. Energy blance studies at this site (Allison and Akerman 1980) show that the surface energy 


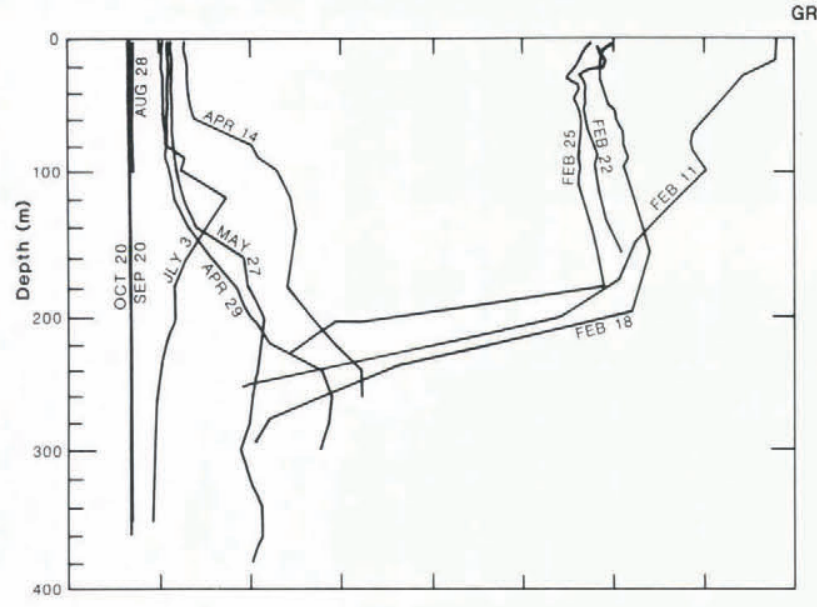

GROWTH
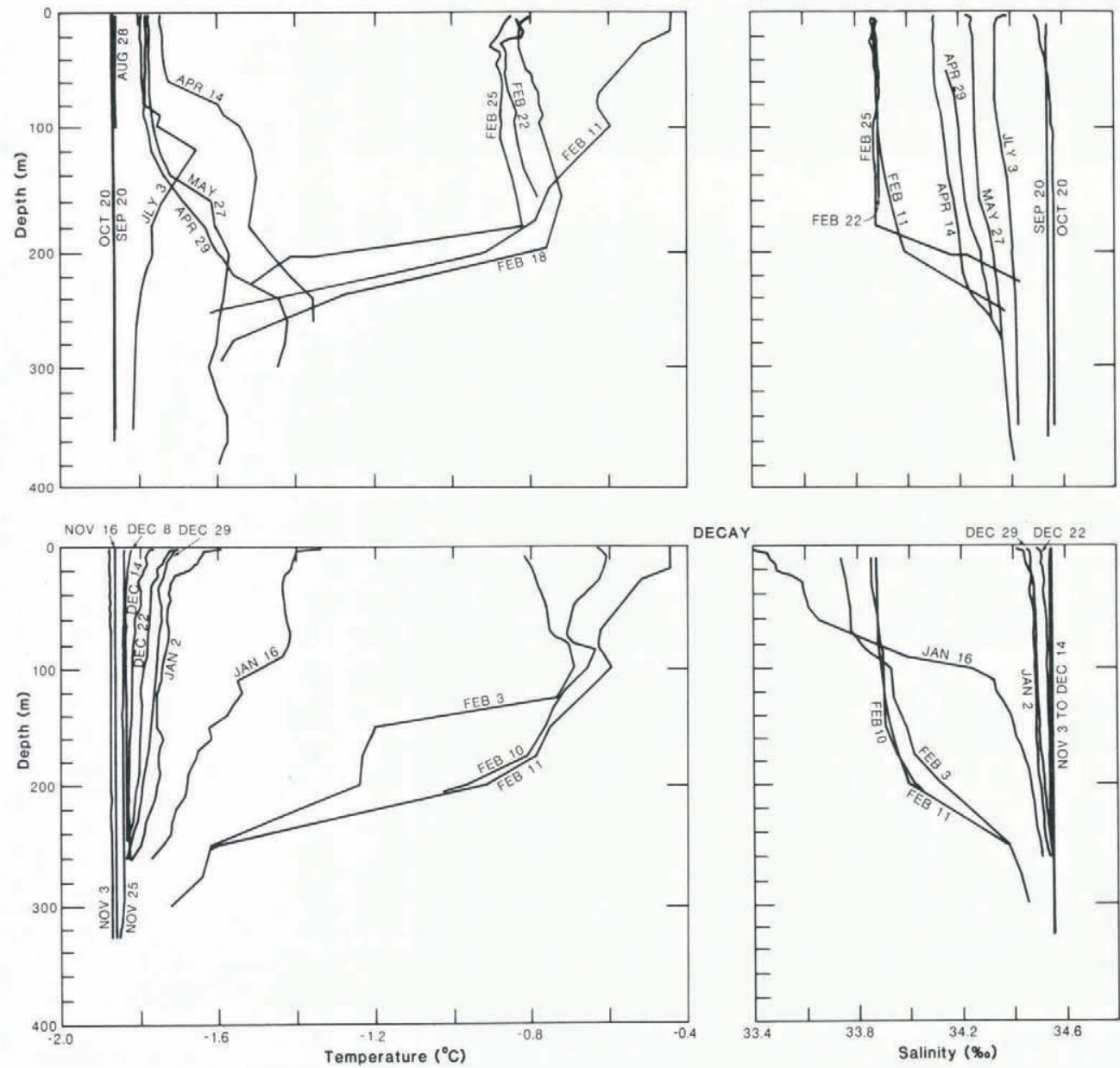

DECA

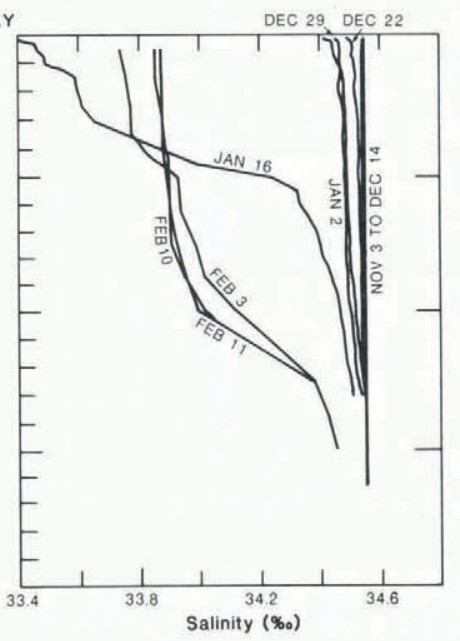

Fig.1. Profiles of temperature and salinity for a number of selected casts between mid February and the end of October (growth) and between the end of October and mid February (decay).

balance becomes negative (indicating loss by the ocean) at this time. This is reflected in the rapid cooling of the surface water after February 11. The upper layers however remain stratified until after the formation of the ice cover in mid March to early April. The pycnocline is then rapidly broken down by haline convection as brine is rejected from the ice. The salinity of the total column steadily increases while the temperature decreases as the ice cover grows to its maximum thickness of $1.8 \mathrm{~m}$ at the end of October.

These changes in water mass with ice growth are also shown in the $T-S$ diagrams of Figures $2 \mathrm{a}$ to $2 \mathrm{~h}$. Initially surface waters are cooled without change in salinity but after ice formation the salinity of the total column is increased and cooled (from the top down) to near the freezing point. By September the water mass is isothermal with a constant salinity.

Changes during the period of ice decay are illustrated in the bottom part of Figure 1 and in the $\mathrm{T}-\mathrm{S}$ diagrams Figures $2 \mathrm{~h}$ to 21 . There is little change in the salinity of the water column under the ice from early November to mid December although the temperature increases slowly during this time. From the second half of December through to the end of January there is a large increase in the temperature of the column and a decrease in salinity. The decrease in salinity is in part due to ablation at the bottom of the ice sheet but is mostly due to freshwater runoff from the nearby plateau, where large melt streams occur in late December and early January. The profile of January 16 (Figure 1) shows injection of plateau meltwater (identifiable from T-S diagram Figure $2 \mathrm{k}$ ) not only at the surface, but also from the bottom of the ice cliffs to a depth of 100 metres.
The ice cover broke out in the last week of January and from then till mid February the water gained heat from the atmosphere. There is little change in salinity during this period but the freshwater input from the plateau is well mixed by strong winds (several events with gusts to $150 \mathrm{~km} \mathrm{~h}^{-1}$ ) and a summer pycnocline forms again at about $200 \mathrm{~m}$ depth.

The change of salinity and temperature with time at a number of standard levels is shown in Figure 3. The largest changes occur at or near the surface but there are significant seasonal changes to a depth of 250 m depth.

\section{THE SALT BUDGET}

Changes in the total salt content of the water column to $250 \mathrm{~m}$ depth have been calculated from salinity profile data and are shown in Table 1. The various sources and sinks of salt include brine ejected from the sea ice, meltwater runoff from the plateau, melt of the sea ice, exchange with the water below 250 $\mathrm{m}$ depth, and horizontal advection into the site.

Growth of the sea ice cover and the changes in ice salinity are shown in Figure 4 . Salt ejected from the ice or removed by ice melt has been calculated from these data but the other source and sink terms in the salt budget are calculated as a remainder.

Table 1 shows the average salt budget $(\mathrm{kg}$ of salt per square metre per day in or out) for six different periods during the year when different physical processes are dominant. There is no change in salinity of the column while the water is cooled to freezing. After ice formation and during the initial period of rapid ice growth, there is an increase in the total salt content of the water which can only be partly explained 


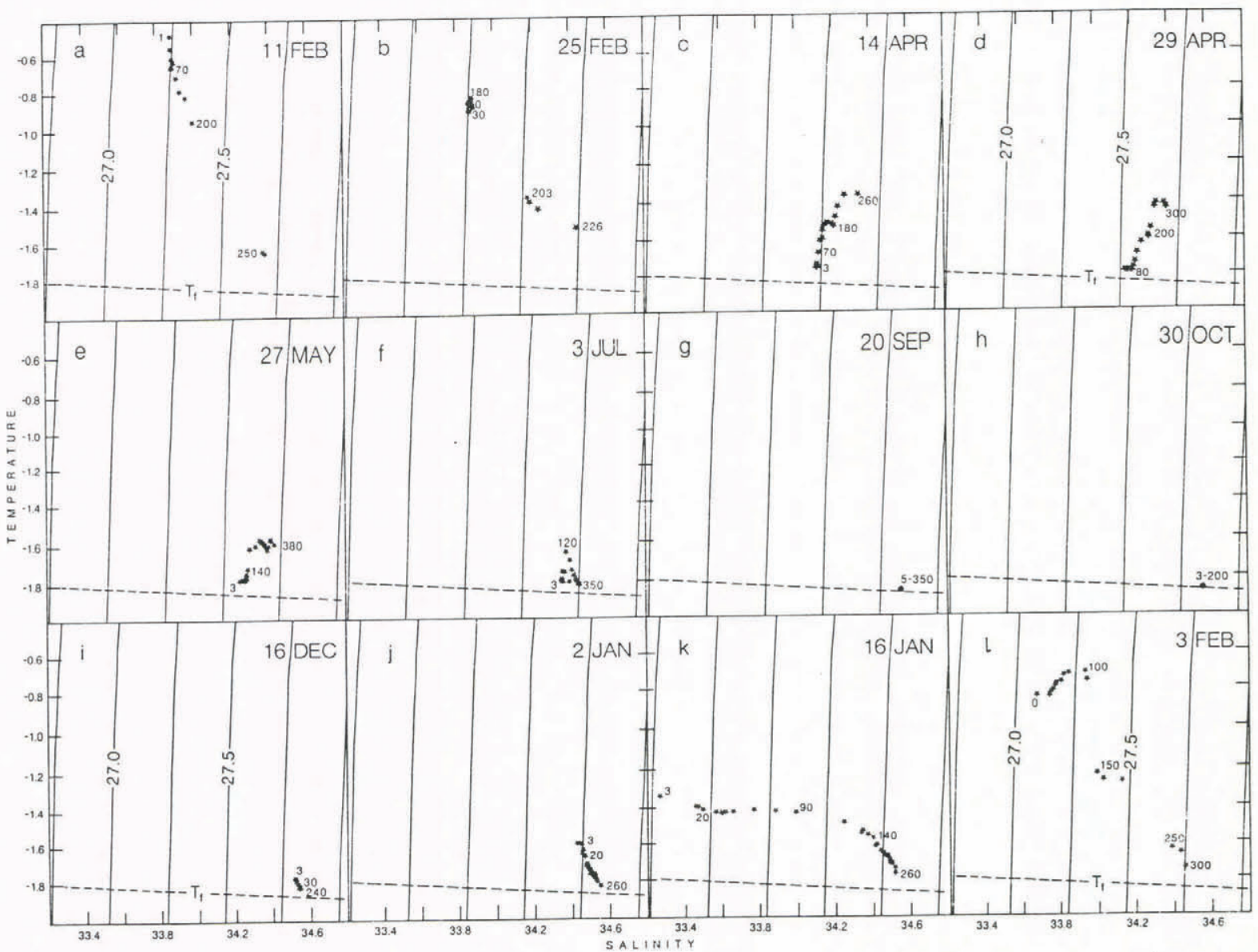

Fig.2. Temperature-Salinity diagrams for selected casts. The figures beside the symbols indicate depth in metres. Lines of constant $\delta_{\mathrm{T}}(27.0,27.5, \ldots)$ and the Knudsen freezing point curve are also shown.

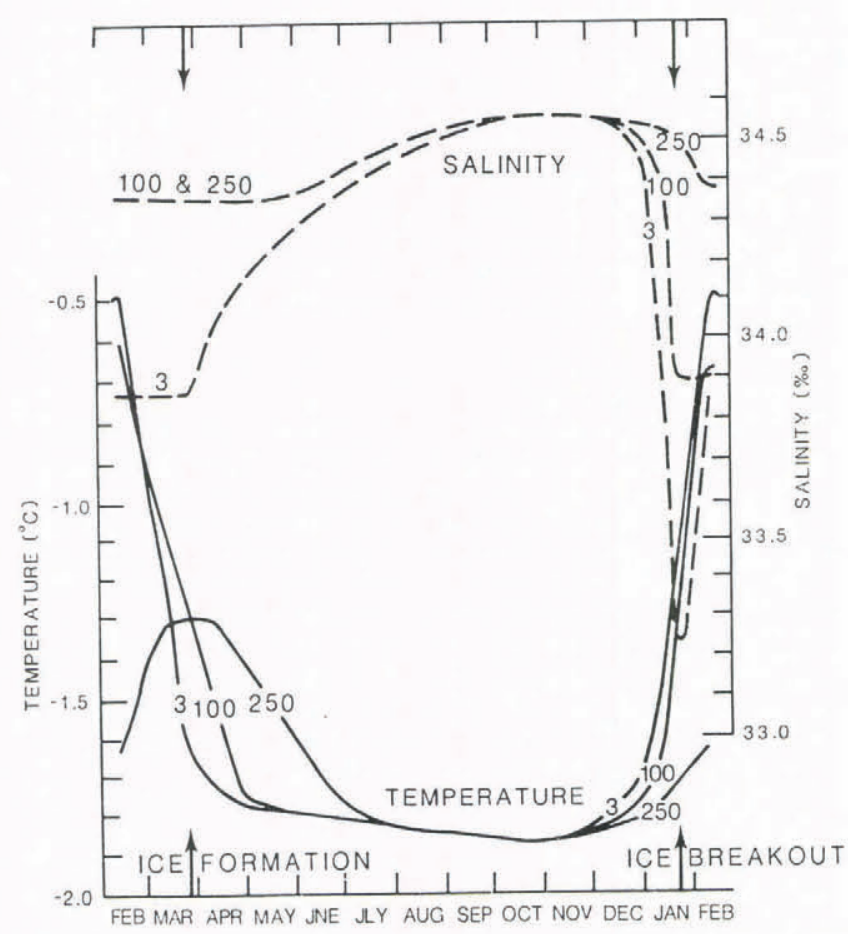

Fig.3. Seasonal changes in salinity and temperature at $3 \mathrm{~m}$, $100 \mathrm{~m}$ and $250 \mathrm{~m}$ depth.

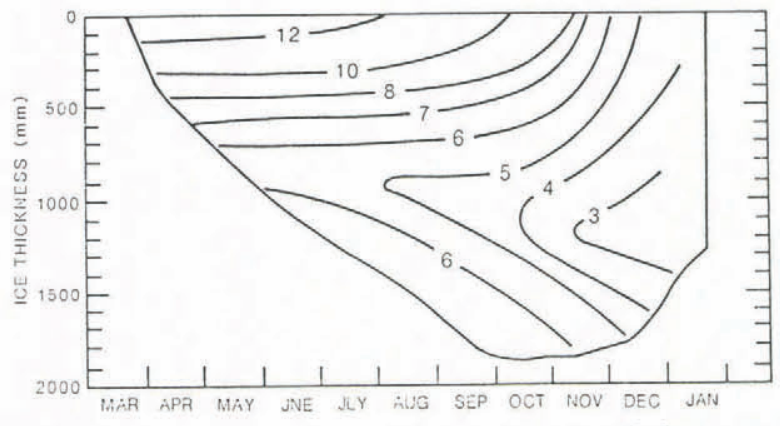

Fig.4. Sea ice thickness (millimetres) and salinity contours $(\%)$.

by brine ejection from the ice. More than twice as much salt is advected into the region as is ejected from the growing ice cover. From May to the end of October the ice cover continues to grow, but more slowly, and the average salinity of the ice also decreases. Salt is suplied to the water column from the ice at rate of only half of that during the period of rapid ice growth and while advection of salt still remains important, it also decreases.

Bottom ablation of the ice provides a negative salt flux from the beginning of November but melt water runoff from the plateau, which commences in early December, provides most of the salinity decrease. The sea ice melt contiues at an accelerated rate in January but the plateau melt runoff during this time becomes 
TABLE 1. SALT BUDGET OF THE WATER COLUMN TO $250 \mathrm{M}$ DEPTH (KG (OF SALT) $\mathrm{M}^{-2}$ $\left.\mathrm{DAY}^{-1}\right)$.

\begin{tabular}{|c|c|c|c|c|c|c|}
\hline $\begin{array}{c}\text { Period } \\
\text { (No. of days) }\end{array}$ & $\begin{array}{l}\text { Feb. } 11 \text { to } \\
\text { Mar. } 23 \\
(40)\end{array}$ & $\begin{array}{l}\text { Mar. } 23 \text { to } \\
\text { May } 1 \\
\quad(39)\end{array}$ & $\begin{array}{l}\text { May } 1 \text { to } \\
\text { Nov. } 1 \\
\text { (184) }\end{array}$ & $\begin{array}{l}\text { Nov. } 1 \text { to } \\
\text { Dec. } 31 \\
(60)\end{array}$ & $\begin{array}{l}\text { Dec. } 31 \text { to } \\
\text { Feb. } 3 \\
(34)\end{array}$ & $\begin{array}{l}\text { Feb. } 3 \text { to } \\
\text { Feb. } 11 \\
(8)\end{array}$ \\
\hline & $\begin{array}{l}\text { Open water. } \\
\text { Heat loss to } \\
\text { atmosphere }\end{array}$ & $\begin{array}{l}\text { Initial rapid } \\
\text { ice growth. }\end{array}$ & $\begin{array}{l}\text { Cont inued } \\
\text { ice growth. }\end{array}$ & $\begin{array}{l}\text { Some bottom } \\
\text { melt of ice } \\
\text { starting. }\end{array}$ & $\begin{array}{l}\text { Ice melting at } \\
\text { bottom plus } \\
\text { large amounts } \\
\text { of fresh run } \\
\text { off from } \\
\text { plateau. }\end{array}$ & $\begin{array}{l}\text { Ice broken out: } \\
\text { open water. } \\
\text { Heat gain from } \\
\text { atmosphere. }\end{array}$ \\
\hline $\begin{array}{l}\text { Change in } \\
\text { water column } \\
\text { salt content }\end{array}$ & 0.00 & +1.64 & +0.48 & -0.22 & -3.99 & -0.03 \\
\hline $\begin{array}{l}\text { Salt ejected } \\
\text { from ice }\end{array}$ & 0.00 & +0.46 & +0.21 & -0.02 & -0.10 & 0.00 \\
\hline $\begin{array}{l}\text { Remainder: } \\
\text { fresh water in } \\
\text { and ocean } \\
\text { advection }\end{array}$ & 0.00 & +1.18 & +0.27 & -0.20 & -3.89 & -0.03 \\
\hline
\end{tabular}

TABLE 2. HEAT BUDGET OF THE WATER COLUMN TO $250 \mathrm{M}$ DEPTH (MJ $\mathrm{M}^{-2} \mathrm{DAY}^{-1}$ ) (1 MJ $\mathrm{M}^{-2} \mathrm{DAY}^{-1} \equiv 11.57 \mathrm{WM}^{-2}$ ).

\begin{tabular}{|c|c|c|c|c|c|c|}
\hline $\begin{array}{c}\text { Period } \\
\text { (No. of days) }\end{array}$ & $\begin{array}{l}\text { Feb. } 11 \text { to } \\
\text { Mar. } 23 \\
(40)\end{array}$ & $\begin{array}{l}\text { Mar. } 23 \text { to } \\
\text { May } 1 \\
(39)\end{array}$ & $\begin{array}{l}\text { May } 1 \text { to } \\
\text { Nov. } 1 \\
(184)\end{array}$ & $\begin{array}{l}\text { Nov. } 1 \text { to } \\
\text { Dec. } 31 \\
(60)\end{array}$ & $\begin{array}{l}\text { Dec. } 31 \text { to } \\
\text { Feb. } 3 \\
\text { (34) }\end{array}$ & $\begin{array}{l}\text { Feb. } 3 \text { to } \\
\text { Feb. } 11 \\
(8)\end{array}$ \\
\hline & $\begin{array}{l}\text { Open water. } \\
\text { Heat loss to } \\
\text { atmosphere }\end{array}$ & $\begin{array}{l}\text { Initial rapid } \\
\text { ice growth }\end{array}$ & $\begin{array}{l}\text { Continued } \\
\text { ice growth }\end{array}$ & $\begin{array}{l}\text { Some bottom } \\
\text { melt of ice } \\
\text { starting }\end{array}$ & $\begin{array}{l}\text { Ice melting at } \\
\text { bottom plus } \\
\text { large amounts } \\
\text { of fresh run } \\
\text { off from } \\
\text { plateau }\end{array}$ & $\begin{array}{l}\text { Ice broken out: } \\
\text { open water. } \\
\text { Heat gain from } \\
\text { atmosphere. }\end{array}$ \\
\hline $\begin{array}{l}\text { Change in } \\
\text { water column }\end{array}$ & -17.9 & -5.7 & -0.9 & +2.0 & +22.4 & +29.5 \\
\hline $\begin{array}{l}\text { Latent heat } \\
\text { ice freeze/ } \\
\text { melt }\end{array}$ & \multirow{2}{*}{$\begin{array}{r}\text { ICE } \\
\text { FREE }\end{array}$} & +4.8 & +1.6 & -1.3 & -3.7 & \multirow{2}{*}{$\begin{array}{l}\text { ICE } \\
\text { FREE }\end{array}$} \\
\hline $\begin{array}{l}\text { Conduction } \\
\text { into ice }\end{array}$ & & -10.1 & -2.1 & -0.6 & 0.0 & \\
\hline Net radiation & 0 to +4 & \multirow{3}{*}{\multicolumn{4}{|c|}{ PERIOD OF SEA ICE COVER }} & +8 \\
\hline $\begin{array}{l}\text { Sensible heat } \\
\text { exchange } \\
\text { water-atmos. }\end{array}$ & 0 to -7 & & & & & +1 \\
\hline $\begin{array}{l}\text { Latent heat } \\
\text { exchange } \\
\text { water-atmos. }\end{array}$ & -4 to -6 & & & & & -4 \\
\hline $\begin{array}{l}\text { Total water-ice } \\
\text { or water-atmos. } \\
\text { exchange }\end{array}$ & -4 to -9 & -5.2 & -0.5 & -1.9 & -3.7 & +5 \\
\hline Advective heat & $\begin{array}{l}\text { Probably } \\
\text { small }\end{array}$ & -0.5 & -0.4 & +3.9 & +26.1 & $+? ?$ \\
\hline
\end{tabular}


very large. The salinity decrease required to balance the budget $\left(3.89 \mathrm{~kg}\right.$ of salt $\left.\mathrm{m}^{-2} \mathrm{day}^{-1}\right)$ represents an input of about $109 \mathrm{~kg}$ of meltwater per square metre per day. After ice break out at the end of January there is little change in the salt content of the water.

\section{THE HEAT BUDGET}

The changes in heat content of the water column to $250 \mathrm{~m}$ depth (MJ m $\mathrm{m}^{-2}$ day $^{-1}$ ) have been calculated from the measured temperature profiles for the same periods as the salt budget. These and the energy exchanges at the upper surface of the water column are shown in Table 2. During the ice covered period the energy exchanges at the ice-water boundary are the latent heat of ice growth or melt, and conduction through the ice cover to the atmosphere. The conductive heat flux has been estimated from the mean monthly air temperature and ice thickness. Previous studies at this site (Allison 1981) have shown that on average this compares well with the conduction derived from measured ice temperatures.

During the ice free period, the surface energy exchanges are net radiation and the turbulent exchanges of sensible and latent heat. The magnitudes given for these fluxes are representative values from previous energy balance studies over open water at this site (Allison and others 1982). The advective heat flux is calculated as a residual between change in heat content of the water column and the heat exchange between water and sea ice or between water and atmosphere.

For the open water period with heat loss to the atmosphere, the tabulated energy exchanges between ocean and atmosphere are from measurements in mid February only. Both the net radiation loss and the turbulent losses will increase in March and the overall cooling of the water column is proabably due largely to surface losses with little advection. After initial ice formation there is considerable conduction through the thin ice cover, the heat for this coming about equally from the latent heat of ice formation and from the oceanic heat flux to the underside of the ice. The oceanic heat flux of $5.2 \mathrm{MJ} \mathrm{m}^{-2}$ day $^{-1}\left(60 \mathrm{Wm}^{-2}\right)$ is approximately balanced by cooling of the water column. As the ice thickens the conducted flux decreases and the oceanic heat flux drops to about $1 \mathrm{MJ} \mathrm{m}^{-2}$ day $^{-1}$ (12 $\mathrm{Wm}^{-2}$ ), continued cooling of the water column still providing most of this latter energy. A high value of oceanic heat flux which decreases rapidly as the ice growth rate reduces has previously been described at this site (Allison 1981) and is due to heat transfer from the deeper water by haline convection. As the ice growth reduces so does the rate of brine expulsion which drives the convection.

After maximum ice thickness the water column starts to gain heat, despite the removal of heat at the ice-water interface for bottom melt. The oceanic heat flux also increases again, from its winter minimum. In January there is considerable warming of the water mass but this cannot be explained by the fresh meltwater runoff from the plateau. A freshwater input of $109 \mathrm{~kg}$ $\mathrm{m}^{-2}$ day $^{-1}$ required to balance the salt budget would, if at $0^{\circ} \mathrm{C}$ compared to the seawater at $-1.6^{\circ} \mathrm{C}$, only provide $0.8 \mathrm{MJ} \mathrm{m}^{-2} \mathrm{day}^{-1}$. The bulk of the $26 \mathrm{MJ} \mathrm{m}^{-2} \mathrm{day}^{-1}$ required to heat the water and to provide an increased oceanic heat flux must be supplied by oceanic advection.

Finally, after the ice has broken out, the water continues to gain considerable heat. The values of radiation and turbulent energy exchange at the surface that are tabulated for this period are representative of only one short period of measurement during a different year (Allison andAkerman 1982). Differences between seasons could easily lead to an increase in total heat gain from the atmosphere of $100 \%$ or more, but even so this would be inadequate to explain the total warming of the water mass and advection must still play an important role.

For the total annual cycle the overall change in heat of the column is $12 \mathrm{MJ} \mathrm{m} \mathrm{m}^{-2}$, corresponding to a difference in the average column temperature of only $0.01^{\circ} \mathrm{C}$.

\section{DISCUSSION}

Despite very low water current below the ice, oceanic advection plays an important role in both the heat and salt balance at this site. Ocean currents have been measured beneath the ice in Kista Strait and show a tidal variation with a maximum amplitude of $0.05 \mathrm{~m}$ $\mathrm{sec}^{-1}$. Usually they are much less.

From Tables 1 and 2 it can be seen that the salt and heat budgets require a net advection of salt, but little advection of heat, to the site during the winter months. From November onwards there is an increasing oceanic advection of heat to the region, although the salt budget at this time is dominated by freshwater input from the Antarctic ice sheet. The oceanic heat flux from water to the ice also shows an increase at this time and we suggest that the increase in available heat is related to the retreat of the Antarctic sea ice further north. Removal of the ice cover will lead to a net heating of the shelf waters, particularly in December when both solar radiation and temperatures will be at a maximum, and this heat is then available for transport polewards to waters that are still ice-covered.

A double maximum in the heat flux from ocean to the ice has been previously reported for a number of Antarctic coastal sites (Allison 1981). The first peak occurs due to thermohaline convection when the ice is growing rapidly, but the second peak occurs after maximum ice thickness (and after the period of maximum extent of the Antarctic ice). At Mawson this second maximum is related to increased oceanic heat advection and it is possible that widespread heat advection towards the Antarctic coast occurs as the ice extent decreases.

\section{REFERENCES}

Allison I 1981 Antarctic sea ice growth and oceanic heat flux. International Association of Hydrological Sciences Publication 131 (Symposium at Canberra 1979 - Sea Level, Ice and Climatic Change): 161-170.

Allison I, Akerman G 1980 Sea ice and ocean energy balance studies at Mawson, Antarctica. International Association of Hydrological Sciences Publication 124 (Symposium at Seattle 1977 - Sea Ice Processes and Models): 347-359.

Allison I, Tivendale C M, Akerman G J, Tann J M, Wills R H 1982 Seasonal variations in the surface energy exchanges over Antarctic sea ice and coastal waters. Annals of Glaciology 3: 12-16

Brennecke W 1921 Die ozeanographischen arbeiten der Deutschen Antarktischen Expedition 1911-1912. Archiv der Deutschen Seewarte 39: 1-214

Foster T D, Carmack E C 1976 Frontal zone mixing and Antarctic Bottom Water formation in the southern Weddell Sea. Deep-Sea Research 23: 301-317

Lewis E L, Walker E R 1970 The water structure under a growing sea ice sheet. Journal of Geophysical Research 75: 6836-6845

Neal V T, Crew H, Broome R 1976 Oceanographic measurements under winter sea ice in McMurdo Sound. Antarctic Journal of the United States 11: 235-239

Wakatsuchi M 1982 Seasonal variations in water structure under fast ice near Syowa Station, Antarctica, in 1976. Antarctic Record 74: 85-108 